\title{
The Systematic Analysis of New-type Urbanization in Public Service Construction System
}

\author{
Ji Shaozhi, a \\ ${ }^{1}$ Guangdong Polytechnic Normal University, No. 293, Zhongshan Avenue, Tianhe District, \\ Guangzhou City, Guangdong Province, China \\ a563927941@qq.com
}

\begin{abstract}
Keywords: Urbanization; System; Public services; Control; Management
Abstract. What kinds of aspects are included in public services of urbanization? How many problems are there? How to solve them? In this paper, the author applies relevant systematic and scientific theories to treat the construction of public service problems as a system, and considers basic public services, social public services, economic public services and public safety services as four subsystems for the public services construction system of urbanization. First of all, the author constructs the construction model of connotation system for public services system, and then analyzes and organizes the four subsystems. Last but not least, refers to four dimensions which are basic public service building, economic public service support, social public service promotion and public safety service safeguard, a system engineering method is applied to come up with the corresponding countermeasures and suggestion, and the public services problems management and control structural model is constructed.
\end{abstract}

\section{Research Status and Connotation Structure Model for Public Services of Urbanization}

In the rising process of urbanization climax, the government and relevant departments gradually have increasing attention to public services. In basic public services, Financial Department proposed an idea in Notification on Applying the Governmental and Social Capital Cooperation Model in 2014: the governmental and social capital should establish a long-term cooperative relationship on infrastructures and public service field. In terms of economic public services, Chinese government proposed in 2016 in Outline of the Thirteenth Five Year Plan for National Economic and Social Development to promote the coordinated development of new-type urbanization and new-type rural construction, and developing characteristic county economy. With regards to social public services, the State Council in 2014 proposed to establish a unified basic old-age insurance of urban and rural residents in the country from People's Republic of China Social Insurance Act. In the aspect of public service, in 2014, the State Council issued New Urbanization Plan (2014-2020 years) stressed the people oriented and proposed to ensure the safety of the employees and the public.

Domestic and overseas have already gotten some research achievements on studying public services of urbanization. On the one hand, Baer (1985) studied the connotations of public services and divided urban public services into three categories, including governmental regulation, cooperative production and government services ${ }^{[1]}$. Jones (1977) divided it into non-fixed services that are provided directly to families or neighbors ${ }^{[2]}$. McLafferty (1984) studied evaluations of public services and applied the correlation coefficient brought by resident incomes and service facilities to measure public services ${ }^{[3]}$. Warner Mildred (2002) showed that under the circumstance of equal measure space or fair territory, the quantitative index that per capita index is used to measure public services is still widely applied ${ }^{[4]}$. On the other hand, Li Junpeng (2005) studied connotations of public services and divided public services into maintenance public services, economic public services and social public services ${ }^{[5]}$. Based on Maslow's hierarchy of needs, Chen Yunliang (2010) divided public services provided by the government for the society into survival public services, public safety services and developmental public services ${ }^{[6]}$. Guo Bin (2009) studied evaluations of public services and showed that the research of public service evaluation index should be promoted from index system design methods, public administration value, governmental function positioning, evaluation 
dimensions, tool selection, index selection, and weight definition ${ }^{[7]}$. Zhang Gang (2008) et al constructed the public service quality evaluation index system of local governments based on citizen value. The system gets involved in four dimensions, which including functional value, emotional value, social value and perceptional cost ${ }^{[8]}$. The research achievements of the above-mentioned scholars have provided the valuable reference for the current study, but previous studies might be relatively scattered to some extent. As a result, it is necessary to use systematic and scientific theories to further study the specific connotation of public services of new-type urbanization and utilize systematic engineering methods to research countermeasures, hoping to achieve an ideal result of optimal new-type urbanization construction.

In the study, the public service subsystems are studied in the new-style urbanization construction system. The public services of urbanization are considered as a system, which must include basic public services, social public services, economic public services and public safety services. The basic public service subsystem contains a series of services required by enterprise production development in towns, daily production and necessities of residents in urban roads, telecommunications, postal services, and utilities. Economic public service subsystem includes a series of services in financial support, investment attraction, tax preference, and technical promotion for promoting economic development. Social public service subsystem includes a series of services such as education, medical treatment, relief and welfare, which are provided by schools, hospitals, poorhouses and cultural places. Public safety service subsystem includes a series of services in public food quarantine, firemen and policemen to safeguard people's lives and properties. For this reason, the connotation structure system model is firstly constructed, see Figure 1.

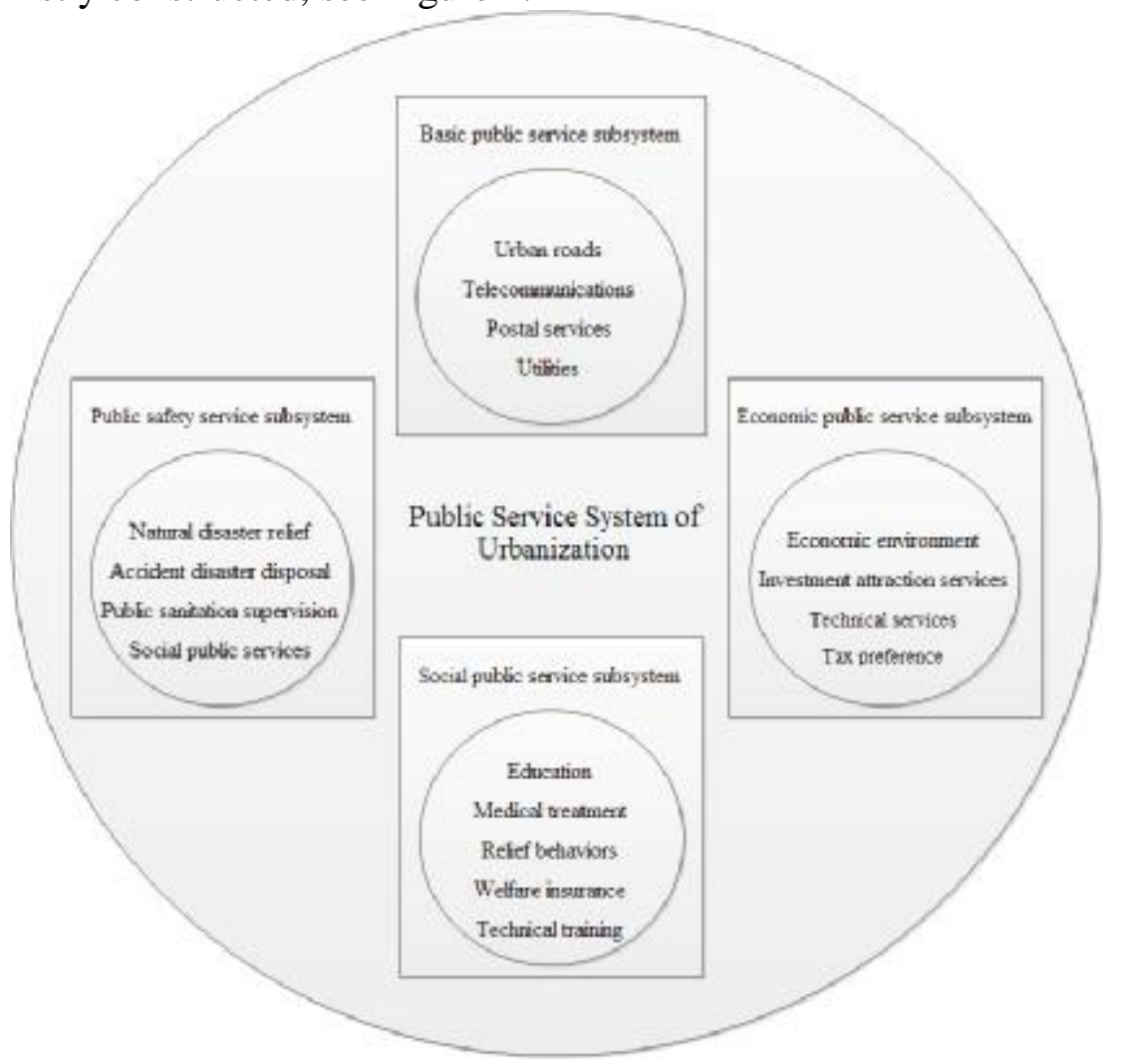

Fig.1 The Connotation Structural System Model in the Public Service System of New-type Urbanization

\section{Existing Problems in the Public Service Construction System of Urbanization}

A computer consists of hardware and software. Similarity, as a public product and service with the property of common consumption, public services also can be divided from the perspective of software and hardware. Hardware services mainly refer to public products, while software services 
refer to service behaviors. Urban public services are composed of public products and public service behaviors.

\section{Insufficiently Reasonable Public Service Planning in Urban Infrastructures and Thoughtless}

Correlation. Due to unreasonable planning of public products and public service behaviors in urban public infrastructure services and thoughtless correlation in urbanization development, infrastructure supply and updating, service behavior norms and supervision, as well as right-protection awareness of audiences, lots of problems are presented. As for public products in road construction, for example, Zhejiang, Fujian and Hunan took place secondary disasters for heavy rainfall, flood disasters, landslide and mud-rock flow successively from June to July 2016. In addition to natural factors, it might be also related to drainage and road facilities, because it gave no consideration to dynamic changes of overall water discharge in road sections as heavy rainfall. In addition, traffic jams of urban roads may tend to yearly deteriorate, because old traffic rules and facilities cannot burden the turnover rate which is increasing substantially of populations and vehicles under the urbanization development background. In telecommunications, the bearing capacity of signal base stations has the rising trend by comparing with density of population occupancy, showing the state of relative still. At the same time, the unilateral unequal articles, forceful stipulations and false advertising of telecommunication enterprises in the telecommunication market damage rights and interests of consumers. In terms of postal service construction, there are insufficient postal service facilities, such as post offices, post shops and postal pavilions, etc. There are insufficient supplies in newly developed towns and there are relatively low skills, thus it is hard to meet people's demands for postal communication and utilization of postal services. With regard to utility construction, old-fashioned transformers may overload for dramatically increased electricity consumption, there is water energy waste in Yunnan power stations for improving electric energy production, and there is the slow pavement progress of gas supply lines in urbanization process of surrounding urban areas. About the public service behaviors in urban road construction, the government focuses on constructing public facilities, but neglects attention on managing and safeguarding public facilities. At the same time, urban residents have insufficient maintenance awareness for public facilities and there is short of corresponding popularization and propaganda. In terms of telecommunication construction, there are only a few standardizing systems for telecommunication market subject behaviors, but laws fail to cover the overall behaviors of market subjects. In the meantime, telecommunication market has cut-throat competition in prefectural and municipal areas or below. In addition, infringement on consumer rights and interests should be related to supervision departments and personnel omission in some areas. With regard to postal construction, mail business investment capital is relatively insufficient, affecting postal service quality. At the same time, postal legal system cannot meet the current developmental demand. In terms of utility construction, due to particularity of utility supply subjects, public enterprises will overcharge and conduct tie-in sale. As a matter of fact, common people are short of corresponding right-protection awareness and legal knowledge for such a behavior, resulting in the constant increase of problems.

Insufficient Economic Public Service Management Level of Towns. There are numerous problems in economic public service management level of towns for insufficient management level, thus it is impossible to do multi-dimensional analysis on overall problems in management system. On the one hand, the extensive economic growth mode with the precondition of consuming lots of resources in economic environmental construction of public products has already caused the uncorrectable damage to the environment. In the investment attraction services, affected by investment attraction competition, there is disorder flow of enterprises, land use ratio, and unreasonable plot ratio. In technical services, though the nation has already had the corresponding research and development departments, the conversion ratio of high-tech technologies is only $5 \%$. The proportion that scientific achievements can be transferred into final industrial scale is only one tenth of developed countries. The final technologies to be promoted and used may be greatly less than actual production. The problem is more prominent on construction of the new-type urbanization. In tax preference, there are multiple tax preference policies in China, but micro-miniature enterprises 
have different division standards, affecting implementation effects of preference policies. At the same time, there are diversified and individual preference categories. Moreover, they are frequently replaced, affecting accuracy of execution. On the other hand, financial department that controls economy may have unsmooth communication and poor coordination with environmental protection department in economic environmental construction of public service behaviors. In order to realize short-term benefits, many local governments prefer to sacrifice environment. Also, the current assessment mechanism regards economic index as the leading basis and pays more attention to GDP, but it is lack of diversified and reasonable indexes. In terms of investment attraction, in order to attract enterprises, some local governments use financial capital to subsidize competitive enterprises, award management and buy or sell land without authorization. The service situations of financial support are also limited to the government and these are never opened to the outside. In technical services, there are relatively insufficient talents in the technical department, so it results in low quantity and quality of technical services supply level. In terms of tax preference, some regional policies are short of specific budget control before execution. There is short of close supervision management in the execution process. Moreover, it is also short of corresponding evaluation comments after execution.

Low Matching Degree between Supply Side and Demand Side in Social Public Services of Urban. In the supply relationship of urban social supply services, the balance between supply side and demand side is always insufficient. The supply side development cannot catch up with changes of demand side. Both of them are short of stability. From the perspective of public products, educational construction, hardware supporting facilities and teachers may have the great deviation for regions and school reputation. In terms of medical treatment service construction, it is impossible for urban residents to avoid from "the difficulty of getting medical services". Such a phenomenon shows the insufficient medical facilities and quality. With regard to social relief construction, majorities of cities will have a phenomenon that "vagrants sleep under the platform bridge. The number of people in relief stations has already exceeded the maximum capacity. At the same time, as the primary capital resource in relief services, constraint and limitation of financial appropriation may restrain the relief work to some extent. In addition, insurance system is lack of dynamics in welfare insurance construction. The same insurance system may be hard to own uniformity in different areas. At the same time, insurance contents are singular and cannot meet multi-level demands of consumers. From the perspective of technical training, the dramatically increased migrant workers and demand uncertainty, technical training categories and demands in public welfare have the low integrating degree. At the same time, implementation of supporting facilities in training is improper. From public service behaviors, the modern educational mode in educational construction may tend to spread theoretical knowledge, resulting in shortage of practical ability for some students. In terms of medical service construction, service quality control is a prominent problem. It is easy to take place long queueing time and short time to see a doctor in hospitals. In addition, medical workers have bad attitudes and some medical workers take money from patients additionally. In social relief construction, relief contents often get involved in different departments and different interest relationships. Every department does thing in its own way as implementing relief. There is no interconnection in information, resulting in relief leakage and repeated relief. Also, lots of people and areas need relief, but there are insufficient grass-roots savers in counties and villages, resulting in low temporary relief ability. In terms of welfare insurance, it is said that the proportion of migrant workers in social insurance and medical insurance in 2014 was only 20\%. With the yearly increase of migrant workers, the total number of migrant workers who cannot enjoy social medical insurance is also rising. The causes of these phenomena are attributed to insufficient schooling of migrant workers and weak right-protection awareness. In terms of technical training, there is no specific safeguard in expenditure investment or insufficient enthusiasm in training. In addition, people have no positive enthusiasm for independent participation in training, resulting in unsmooth training in the process.

Insufficient Maturity of Public Service Coordination Mechanism in Public Safety Services of Urban. The public safety service coordination mechanism of urban area is short of the capacity to analyze public safety service hierarchy. So it cannot conduct service and coordination according to 
respective features of components. In public products, multi-aspect help may be sought in natural disaster relief. Or people will gather goods and materials, showing insufficient relief equipment and material storage. In terms of accident disaster disposal, multiple sections and multiple areas may have improper supervision. Some buildings have damaged fire control equipment. All of these affect accident disposal. From the perspective of public sanitation supervision, public sanitation has a wide range. Supervision regulation and complaint channels cannot realize diversity and full coverage. As for social safety, the public security alarm points in most of cities are kept in the dense zones with human traffic, but surroundings are short of corresponding public safety facilities. In public service behaviors, natural disaster relief, disaster prediction and reaction ability are relatively weak. As for accident disaster disposal, low maturity of early warning evaluation mechanism and shortage of self-rescue ability of people will intensify dangerousness of accidents. In terms of public sanitation supervision, the deterioration of public sanitation is attributed to unstrict supervision and punishment strength in supervision departments and enterprises violating regulations cannot realize their problems driven by benefits. As for social security services, safety knowledge propaganda strength in relevant departments is insufficient. The knowledge propaganda action always "goes through the motions". Self-rescue and rescue knowledge of urban residents is deficient. They always implement blind self-rescue in emergency situations.

In the four subsystems for public service construction system of urbanization, the perfection of public urbanization products and safeguard of public service behaviors are mutually connected and interacted. In the study, the author points out relevant problems for every subsystem from two aspects of public products and public service behaviors, as shown in Table 1.

Tab.1 Problems of Public Service Construction System

\begin{tabular}{|c|c|c|c|}
\hline Types & $\begin{array}{l}\text { Public } \\
\text { service }\end{array}$ & \multicolumn{2}{|c|}{ Existing problems } \\
\hline & & Public products & Service behaviors \\
\hline \multirow{4}{*}{$\begin{array}{l}\text { Basic } \\
\text { public } \\
\text { services }\end{array}$} & Urban roads & $\begin{array}{l}\text { 1. Imperfect supporting facilities } \\
\text { 2. Road traffic congestion }\end{array}$ & $\begin{array}{l}\text { 1. Insufficient maintenance degree of the } \\
\text { government } \\
\text { 2. Weak conscientious maintenance awareness } \\
\text { of urban residents }\end{array}$ \\
\hline & $\begin{array}{l}\text { Telecommu } \\
\text { nications }\end{array}$ & $\begin{array}{l}\text { 1. Unequal equipment distribution } \\
\text { 2. Unfair unilateral agreements of } \\
\text { telecommunication enterprises }\end{array}$ & $\begin{array}{l}\text { 1. Insufficient legal system maturity in } \\
\text { telecommunication industry } \\
\text { 2. Serious omission of supervision } \\
\text { organizations }\end{array}$ \\
\hline & $\begin{array}{c}\text { Postal } \\
\text { services }\end{array}$ & $\begin{array}{l}\text { 1. Fewer website quantities } \\
\text { 2. Low technical level }\end{array}$ & $\begin{array}{l}\text { 1. Insufficient involvement loads } \\
\text { 2. Lagging legal system }\end{array}$ \\
\hline & Utilities & $\begin{array}{l}\text { 1. Fail to load electricity consumption of } \\
\text { transformers in some areas } \\
\text { 2. Water abandoned problems in some } \\
\text { hydropower stations } \\
\text { 3. Slow construction progress of natural gas } \\
\text { pipelines }\end{array}$ & $\begin{array}{l}\text { 1. Product tie-in sale in public enterprises } \\
\text { 2. Deficient right-protection awareness of } \\
\text { residents }\end{array}$ \\
\hline \multirow{4}{*}{$\begin{array}{l}\text { Economic } \\
\text { public } \\
\text { services }\end{array}$} & $\begin{array}{l}\text { Economic } \\
\text { environment }\end{array}$ & $\begin{array}{l}\text { 1. Extensive growth mode and large resource } \\
\text { wastage } \\
\text { 2. Large economic influences }\end{array}$ & $\begin{array}{l}\text { 1. Low environmental protection and economic } \\
\text { development coordination degree } \\
\text { 2. Excessive economic attention in assessment } \\
\text { system and shortage of diversified indexes }\end{array}$ \\
\hline & $\begin{array}{c}\text { Investment } \\
\text { attraction } \\
\text { services }\end{array}$ & $\begin{array}{l}\text { 1. Disorder enterprise flowing } \\
\text { 2. Unclear land use }\end{array}$ & $\begin{array}{l}\text { 1. Fuzzy governmental functional range } \\
\text { 2. Opaque capital purposes }\end{array}$ \\
\hline & $\begin{array}{l}\text { Technical } \\
\text { services }\end{array}$ & $\begin{array}{l}\text { 1. Low conversion rate of production } \\
\text { technology } \\
\text { 2. Insufficient technical supply degree }\end{array}$ & $\begin{array}{l}\text { 1. Fewer categories of technical consulting } \\
\text { services } \\
\text { 2. Low service level of department personnel }\end{array}$ \\
\hline & $\begin{array}{l}\text { Tax } \\
\text { preference }\end{array}$ & $\begin{array}{l}\text { 1. Limited range of applicable enterprises } \\
\text { 2. Repeatability of tax preference }\end{array}$ & $\begin{array}{l}\text { 1. Shortage of budget control } \\
\text { 2. Imperfect pre-event and post-event } \\
\text { management }\end{array}$ \\
\hline
\end{tabular}


Table 1. Cont.

\begin{tabular}{|c|c|c|c|}
\hline \multirow{5}{*}{$\begin{array}{l}\text { Social } \\
\text { public } \\
\text { services }\end{array}$} & Education & $\begin{array}{l}\text { 1. Low level of hardware facilities } \\
\text { 2. Shortage of high-quality teacher resources }\end{array}$ & $\begin{array}{l}\text { 1. Shortage of fairness in resource distribution } \\
\text { 2. Emphasize theory and neglect practice in } \\
\text { educational forms }\end{array}$ \\
\hline & $\begin{array}{l}\text { Medical } \\
\text { services }\end{array}$ & $\begin{array}{l}\text { 1. Inconsistency between supply quantity and } \\
\text { demand quantity } \\
\text { 2. Shortage of rationality in structure and } \\
\text { layout }\end{array}$ & $\begin{array}{l}\text { 1. Low service quality } \\
\text { 2. Corruption problems in medical system }\end{array}$ \\
\hline & $\begin{array}{c}\text { Relief } \\
\text { behaviors }\end{array}$ & $\begin{array}{l}\text { 1. Insufficient relief stations } \\
\text { 2. Low relief capital limit }\end{array}$ & $\begin{array}{l}\text { 1. Shortage of coordination and dynamics in } \\
\text { relief system } \\
\text { 2. Insufficient temporary relief ability }\end{array}$ \\
\hline & $\begin{array}{l}\text { Welfare } \\
\text { insurance }\end{array}$ & $\begin{array}{l}\text { 1. Shortage of dynamics in insurance system } \\
\text { 2. Single social insurance contents }\end{array}$ & $\begin{array}{l}\text { 1. Narrow insurance coverage of migrant } \\
\text { worker groups } \\
\text { 2. Poor right-protection ability of migrant } \\
\text { worker groups }\end{array}$ \\
\hline & $\begin{array}{l}\text { Technical } \\
\text { training }\end{array}$ & $\begin{array}{l}\text { 1. Fewer categories of training contents } \\
\text { 2. Insufficient training facilities }\end{array}$ & $\begin{array}{l}\text { 1. Insufficient provision strength } \\
\text { 2. Weak autonomous training sense of people }\end{array}$ \\
\hline \multirow{4}{*}{$\begin{array}{l}\text { Public } \\
\text { safety } \\
\text { services }\end{array}$} & $\begin{array}{l}\text { Natural } \\
\text { disaster } \\
\text { relief }\end{array}$ & $\begin{array}{l}\text { 1. Incomplete relief equipment } \\
\text { 2. Limited relief resource storage }\end{array}$ & $\begin{array}{l}\text { 1. Immature predictive system } \\
\text { 2. Low response sensitivity of relief }\end{array}$ \\
\hline & $\begin{array}{l}\text { Accident } \\
\text { disaster } \\
\text { disposal }\end{array}$ & $\begin{array}{l}\text { 1. Fail to realize full coverage in monitoring } \\
\text { equipment } \\
\text { 2. Invalid fire control alarm system and } \\
\text { equipment }\end{array}$ & $\begin{array}{l}\text { 1. Imperfect early warning evaluation } \\
\text { mechanism } \\
\text { 2. Low self-rescue ability of people }\end{array}$ \\
\hline & $\begin{array}{c}\text { Public } \\
\text { sanitation } \\
\text { supervision } \\
\end{array}$ & $\begin{array}{l}\text { 1. Imperfect punishment regulations } \\
\text { 2. Shortage of diversity in complaint channels }\end{array}$ & $\begin{array}{l}\text { 1. Lack of market supervision } \\
\text { 2. Irregular thoughts in illegal enterprises }\end{array}$ \\
\hline & $\begin{array}{l}\text { Social safety } \\
\text { services }\end{array}$ & $\begin{array}{l}\text { 1. Shortage of flexibility in equipment layout } \\
\text { 2. Insufficient public facilities in alarm points }\end{array}$ & $\begin{array}{l}\text { 1. Insufficient propaganda strength } \\
\text { 2. Insufficient self-rescue and rescue awareness }\end{array}$ \\
\hline
\end{tabular}

\section{Management and Control for Public Service System of Urbanization}

By aiming at problems in four subsystems in public service construction system in new-type urbanization construction process and beginning with systematic perspective, it must apply systematic viewpoint to strengthen management and regulation from the aspects which are solving public service problems, perfecting public service contents, promoting public service level.

Lay Emphasis on Integrality and Dynamics and Perfect Basic Public Services. In order to perfect public services, it must focus the attention on integrality and dynamics of the system, conduct overall planning and systematic management, and improve attention and popularity. For public products, the government should recognize and plan from the overall perspective, further know about correlation among public facilities, social development and people's demands, and pay close attention to the changes of dynamics. First of all, better planning, design and update public facilities are needed, such as the urban development of drainage, road facilities and power supply facilities need to adapt to the demand of next decades. Secondly, better understand the stages of regional development and construct corresponding public facilities according to actual regional circumstances. At last, it must increase the troubleshooting strength of public facilities, ensure availability of public facilities and improve use ratio of public facilities. In service behaviors, the government should supervise, manage and control public service supply from two aspects, including service suppliers and service beneficiaries. On the one hand, service suppliers should construct the perfect legal system and conduct constrained control for public service behaviors. On the other hand, service beneficiaries should enlarge propaganda strength and improve urban residents' protective consciousness for public facilities in the form of award report and punishment education. 
Improve Diversity and Coordination, and Support Economic Public Services. For economic public service subsystem, it must aim at diversity and coordination, standardize the behavior of governmental economic management department, and realize environmental protection and common economic development. For public products, it must coordinate with the multi-level relationship in economy and environment, government and enterprises, production and technology, regulation and users. First of all, the economic growth mode must be improved and resource use ratio needs to be increase well. Secondly, standardization of market competition required better maintenance, propaganda reinforcement, enterprise orientation scientifically guidance, regulations formulation, and standardize governmental behaviors. Thirdly, technical conversion ratio request improve adhesiveness and coordination of technical research and development, promotion and service. In the end, it must improve working efficiency of tax departments, eliminate repeated and old-fashioned regulations, and implement tax preference policy objects. In terms of public service behaviors, it must conduct multi-dimension supervision on overall chain of event development. First of all, it must coordinate with the relationship between environmental protection department and economic management department, carry out economic development activities relating to environment, establish the governmental assessment system, set up multiple indexes concerning people's life and environment, and weaken proportion of economic indexes. Secondly, it must set up the corresponding supervision departments, conduct supervision management on market regulation, training provision and taxation, formulate definite regulations, standardize governmental intervention behaviors for enterprise activities and market, formulate laws to abide by, and insist in fairness and transparency of governmental behaviors. At last, it must grasp diversity of group demands and rationally provide technical training services.

Insist in Stability, Finality and Improve Social Public Services. The social public service improvement subsystem need to insist in stability and finality, enlarge investment strength, and popularize social safeguard knowledge. As for public products, it must definitely improve audiences and use ratio of public products. On the one side, on the basis of the existing public facilities, it must enlarge investment strength and increase public facilities, such as teaching equipment, medical equipment and relief equipment quantity. On the other side, it must allocate public resources rationally and enrich insurance contents. For public service behaviors, it must insist in stability of the current system. To begin with, it must improve working ability and work quality of personnel in education, medical treatment and training through assessment and supervision mechanism. Secondly, for service system, it must improve system work interaction on the precondition of safeguarding stability and knowing about demands. Thirdly, for services, it can improve migrant workers' awareness of purchasing insurance, right-protection awareness and training awareness through leaflets, special introduction and department promotion. Also, the central policy concentration should shift to migrant workers and ensure them to work in towns under the precondition of ensuring that migrant workers enjoy equal social public services.

Close to Hierarchy \& Self-organization, and Safeguard Public Safety Services. The public safety service subsystem refers to hierarchy and self-organization, as well as multi-level allocation resources. It must improve residents' awareness and ability to checking erroneous ideas at the outset. For public products, it must insist in the principles of hierarchical distribution. As for allocation of public products, firstly, it must insist in multiple distributions in dense areas and high crime rate. According to cases in previous years and relevant data of crime rate, it must define the dense areas with high crime rate and enlarge investment strength of personnel and resources. Secondly, it must allocate safety service resources in remote areas and areas with low crime rate, so as to improve resource use ratio. Thirdly, it must put an end to no distribution and it must ensure there is public safety services with populations and realize full coverage and multiple levels of public safety products. In public service behaviors, it must enlarge propaganda strength of safety problems and convey safety problem control information to urban residents through schools, units, families and society, and set up punishment system, and form the social atmosphere of cracking down illegal criminal activities similar to "aunt group" enthusiasm in Chaoyang District, Beijing. On the other hand, it must perfect 
early warning evaluation mechanism and supervision mechanism, conduct the effective early warning evaluation for disasters and conduct the strict supervision for illegal behaviors.

The suggestion of managing and controlling public service system of new-type urbanization is analyzed and proposed from four aspects, including basic public service maintenance, economic public service support, social public service promotion and public safety service safeguard, see Figure 2 .

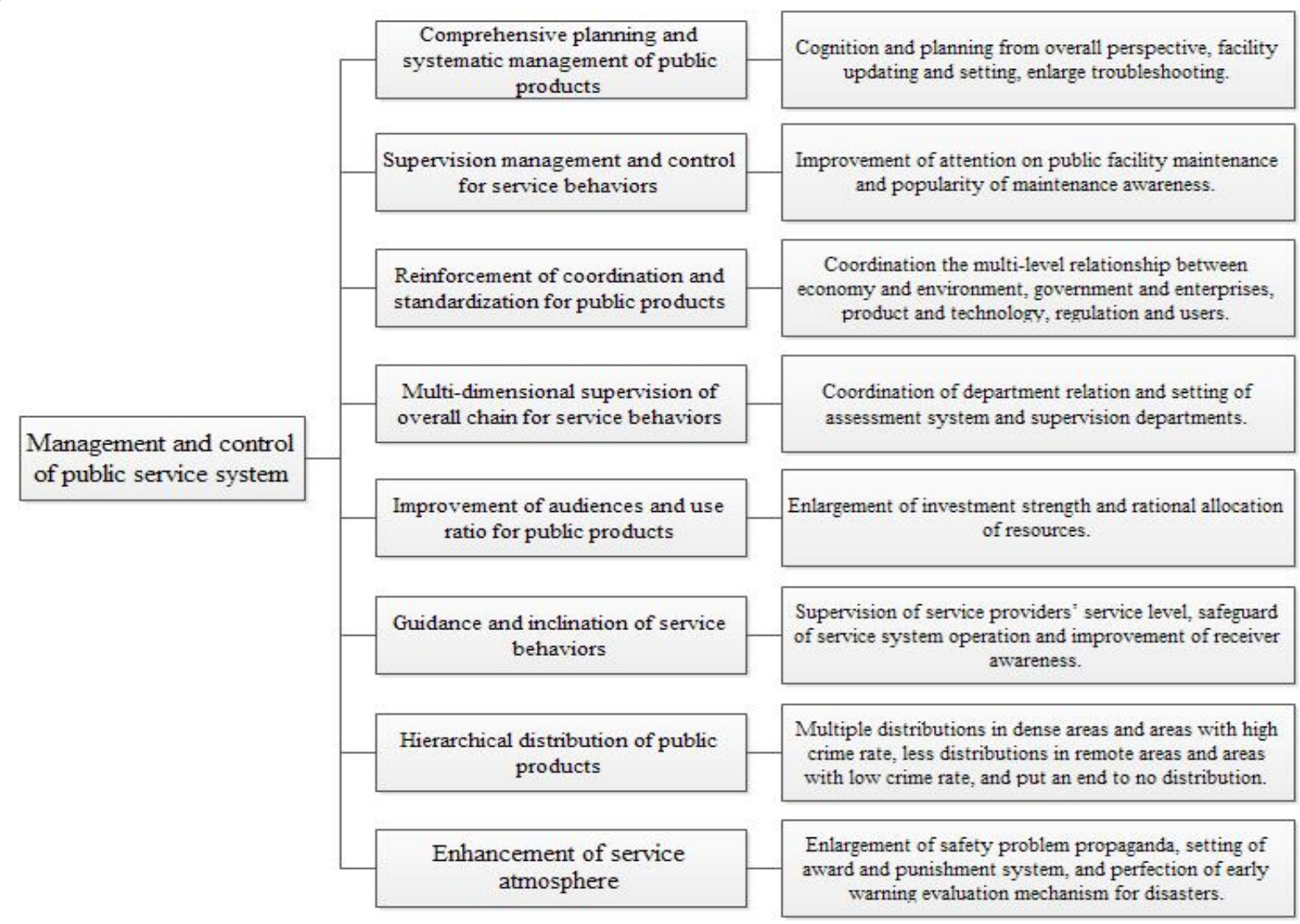

Fig.2 Model of Public Service System Management and Control Structural System

\section{Conclusions}

In the paper, adhering to the combination of practicability and scientificity and beginning with the systematic science, the author regards public service problems as a system, divides it into basic public service maintenance, economic public service support, social public service promotion and public safety safeguard, then conducts the analysis on problems in public service constructions system, and finally uses systematic engineering methods to propose the corresponding countermeasures and suggestion, hoping to provide some reference significance on constructing the new-type urbanization.

\section{References}

[1] Baer and William C: The Journal of Politics Vol. 47 (1985), p. 881-898

[2] Jones, Bryan D. and Kaufman Clifford: Administration \& Society Vol. 6 (1974), p. 337-360

[3] McLafferty and Sara: Political Geography Vol. 3 (1984), p. 33-47

[4] Warner Mildred and Hefetz Amir: Urban Affairs Review Vol. 38 (2002), p: 70-89

[5] Li Junpeng: Public Service Science-Theory and Practice of Governmental Public Services (National School of Administration Press, Beijing 2007)

[6] Chen Yunliang: Modern Law Science Vol. 28 (2006), p. 174-181 
[7] Guo Bin: Journal of Northwest University (Philosophy and Social Sciences Edition) Vol. 39 (2009), p. 118-122

[8] Zhang Gang: Journal of Zhejiang University (Humanistic and Social Sciences) Vol. 38 (2008), p. $31-40$ 